\title{
Analysis of indoor air quality in a naturally ventilated church
}

\author{
Monika Wysocka ${ }^{1, *}$ \\ ${ }^{1}$ Bialystok University of Technology, Faculty of Civil Engineering and Environmental Engineering, \\ Department of Heat Engineering, Wiejska 45E, 15-351 Białystok, Poland
}

\begin{abstract}
The quality of air in sacral buildings is an important factor that affects users. Church buildings are characterized by a specific microclimate, because they accommodate many people in short periods of time, which results in rapid changes in air quality. Sacral buildings usually only have natural ventilation through doors, return air inlets and window leaks, which can cause uneven distribution of fresh air. The aim of this article is to analyze the results of research on the basic parameters of air quality: carbon dioxide, relative humidity and air temperature in the church. The analysis carried out on research results allowed to state that the measured parameters of air quality - the concentration of carbon dioxide and the level of relative humidity significantly exceeded the standards recommendations. High level of air humidity was recorded at $75 \%$. In the analyzed sacral building there is the need to improve air quality in terms of carbon dioxide and relative humidity. Ways of improving air quality, such as installation of mechanical ventilation, will help prevent damage to structures and equipment, and improve comfort of people in the church.
\end{abstract}

\section{Introduction}

The quality of indoor air is an extremely important factor that greatly affects the health and well-being of men, which is why it is the subject of attention of scientists, doctors and engineers. According to the observations made, the reason for malaise and diseases is usually the components present in the immediate environment in which people spend the most time. To overcome the undesirable impact of poor air quality on human health, monitoring and analysis of concentration of pollutants and other compounds that reduce air quality is crucial $[1,2]$.

The category of interior microclimate is inseparably connected with the concept of air quality. It is characterized as a group of various physical and chemical parameters that change over time within the space of a given room. It is an ecosystem in which elements interact with each other and, at the same time, react with the external environment, which allows for creating appropriate conditions for people [3-6].

In general, it can be stated that the indoor air surrounding people creates a microclimate of the interior, which differs in composition from the outside (atmospheric) air. It is subject

\footnotetext{
*Corresponding author: m.wysocka@,doktoranci.pb.edu.pl
} 
to dynamic changes, both in terms of quality and quantity, even in short time intervals, while its quality is influenced by many factors $[5,7-8]$.

First of all, attention should be paid to the harmful factors introduced into the facility together with the ventilation air, for example, dust, plant spores and industrial contamination. In addition, pollutants in a given building are an important issue, and their sources are [9-10]:

- building materials and equipment,

- processes resulting from the presence of room users (emission of $\mathrm{CO}_{2}$ ),

- microbiology in the room (mites, fungi, molds, bacteria).

The issue of thermal comfort is included in the concept of the microclimate. Generally speaking, it is "a state of satisfaction with the thermal conditions of the environment, one in which the thermal balance of the human body is preserved" [11-12].

The thermal comfort of a human is shaped by many factors. The most important is undoubtedly the air temperature, because it mostly affects people through the feeling of thermal comfort. Too high of a temperature value may cause a decrease in psychophysical efficiency (eg drowsiness, decrease in reflexes). Low temperature has an effect of discomfort, causes narrowing of blood vessels and chills. The next condition regulating comfort is relative humidity of the air, and its influence on thermal sensation becomes higher as the ambient temperature increases. Too high of an indoor air humidity (at the level of about $70 \%$ or more) causes the growth of mold, fungi and bacteria in the interiors, and additionally disturbs the evaporation of sweat from the body. On the other hand, low level of humidity, especially in heated interiors, is the cause of drying of mucous membranes. Due to health reasons, the relative humidity should oscillate around 40-70\% [12-14].

The quality of indoor air affects not only people's organisms, but also buildings, especially their construction. Low thermal resistance of building partitions causes the cooling of the object, which is usually associated with a high content of relative humidity in the air [15-16].

Too high of a level of relative humidity, which is one of the components of air quality, has a negative impact on building partitions and interior equipment. Conditions of increased humidity (over 70\%) are a friendly environment for the development of mold and fungi. Spores spread particularly intensively with limited air exchange. In addition, changes in humidity cause the deformation of wooden elements, which is manifested by cracking and swelling, as well as the disintegration of wooden joinery. Additionally, at the dew point temperature, condensation may occur in the building envelope, which leads to the plaster falling off and deterioration of the building structure [16-18].

\section{Air quality in sacral buildings}

The quality of air in churches is an important factor that affects the comfort and well-being of users. The levels of carbon dioxide, relative humidity and air temperature largely shape the microclimate prevailing in the rooms, and thus affect the mood of people staying in a given facility. Church buildings are characterized by a specific microclimate, because there is a large number of people in a relatively short time, which can result in rapid changes in air quality.

Ventilation in sacred buildings usually is carried out the natural way. The process of air exchange usually takes place through the door when people enter and leave the temple. In the literature, it is difficult to find any data on the ventilation requirements for sacral objects, therefore, by comparison to large-volume facilities, such as auditoriums or concert halls, we can estimate the approximate multiplicity of air exchange. For rooms with large cubature, 5-14 exchanges of supply air and 4-12 exchanges for air removed in the facility within an hour are recommended [19-20]. The minimum hourly amount of ventilation air, which guarantees minimum hygiene conditions can be considered $22 \mathrm{~m}^{3} / \mathrm{h}$ per person according to PN EN 13779 [21]. 
The parameter significantly affecting the indoor air quality is carbon dioxide. Due to the temporary nature of the object's use by a large group of people, it is a dynamically changing factor directly affecting the quality of the air. It is generally assumed, that the maximum $\mathrm{CO}_{2}$ concentration in rooms for permanent human residence should be $1,000 \mathrm{ppm}(0.1 \%)$, this is called the hygienic minimum [22]. During circumstances when the hygienic minimum is not being met, depending on individual circumstances, users of premises may experience headaches, impaired concentration, dyspnoea and many other symptoms [23].

Another factor that contributes to forming air quality in a church is temperature. It plays a fundamental role in the thermal comfort of a room's occupants. People gathered in a temple participate in the religious service either in a sitting or standing position, the physical activity is negligible. In a church where conditions of low temperature prevail, a person usually exerts heat to the environment. It should also be noted, that the conditions of the internal environment in a church should not only be aimed at creating comfort for the users (Table.1), but also to adjust the optimal environment to the equipment, which is often historical in nature [24].

Table 1. Recommended values of temperature and relative humidity for the thermal comfort of church buildings' user.

\begin{tabular}{|c|c|c|}
\hline Parameter & Unit & Value \\
\hline Comfort temperature & ${ }^{\circ} \mathrm{C}$ & $12-16$ \\
\hline The base temperature in the building & ${ }^{\circ} \mathrm{C}$ & $6-8$ \\
\hline Dynamics of physical activity & $\mathrm{W} / \mathrm{h}$ & $110-120$ \\
\hline Humidity range & $\%$ & $45-75$ \\
\hline
\end{tabular}

Source: own elaboration based on [24]

According to Cichowicz and Urbaniak [16], the stability of conditions prevailing inside the object is very important, which may be more significant than temperature deviations from the recommended values. The amplitudes of temperature, as well as the relative humidity of air, contribute to the deterioration of equipment and cracking of the sacral object [1717].

In the context of thermal comfort a strong relation exists between relative humidity of air and temperature. Its high level (over 60-70\%) may be the reason for the development of mold, fungi and deterioration of building partitions and equipment. Heating the room with high air moisture content is disadvantageous, because it does not improve thermal comfort. In this situation, it may be a better solution to remove excess moisture using a ventilation system than to overheat the building [17].

In case of paintings, frescoes, wooden polychrome ornaments or decorations being present in the temple, the humidity conditions should resemble the museum climate. According to PN-EN 15757: 2012, in order to limit the physical damage caused by the climate on hygroscopic materials that are exposed long term in museum or church conditions, the relative humidity should be in the range of $40-60 \%$, with a fluctuation range of $+/-10 \%[25]$.

\section{Description of the object}

The church dedicated to the Immaculate Conception of the Blessed Virgin Mary in Tryczówka is located $22 \mathrm{~km}$ south of Białystok, in the Podlasie Voivodship, in the IV climate zone. The temple was built in 1930 based on a design by architect Leonardo Kario. The body of the building relates to simplified Romanesque forms, it was erected from airbricks on a rectangular plan, as an indoor building with a tower on the axis, extended in front of the face of the facade. On the opposite side a lower presbytery was 
built, enclosed by two sacristies. The body of the temple was covered with a gable roof. After 1994 a general renovation of the temple was carried out. The foundations and walls of the church were strengthened, the building was plastered and insulated [26].

The church building has stained single glass windows, with poor insulating properties. Ventilation in the facility takes place naturally, through five ceiling openings, main doors, side doors and leaks. The building is equipped with an air heating, which is carried out using a Benson oil furnace. The interior of the temple, where measurements of basic air quality parameters were made, has the following dimensions: length - $24 \mathrm{~m}$, width - $12 \mathrm{~m}$, height $-12 \mathrm{~m}$. The cubature of the building is approximately $3400 \mathrm{~m}^{3}$.

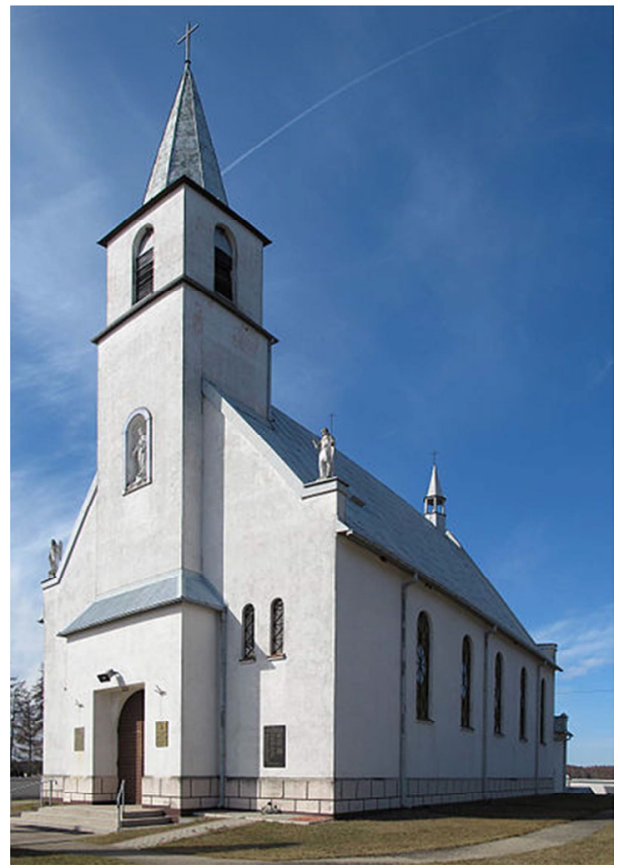

Fig. 1. View of the church (own collection).

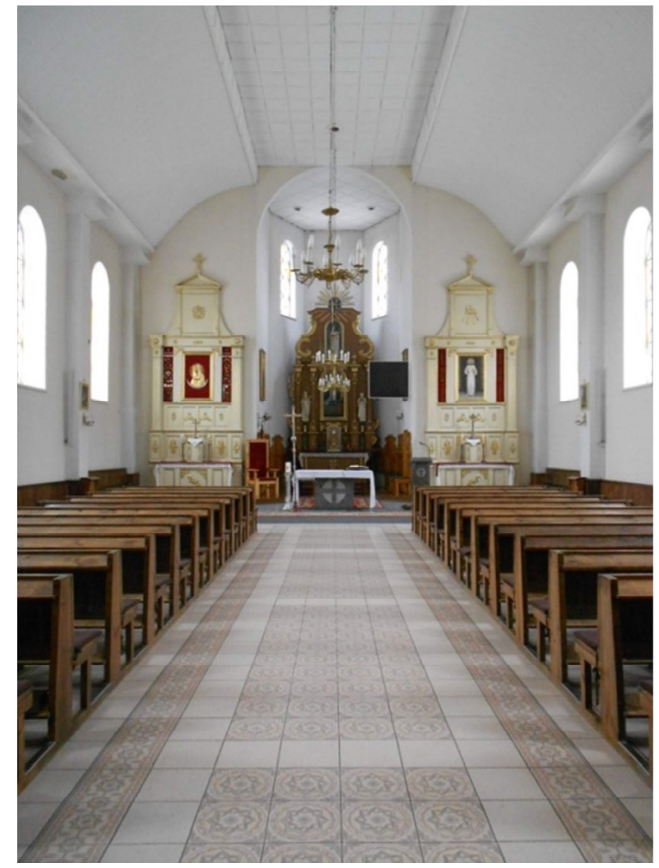

Fig. 2. Interior of the Church of the Immaculate Conception of the Blessed Virgin Mary in Tryczówka (own collection).

\section{Research methodology}

In order to determine the quality of indoor air, an air test was carried out in the parish church in the village of Tryczówka. Examination of basic air parameters was carried out using a Testo 435-4 multifunction measuring device and a compatible IAQ probe. Testo 435-4 is suitable for measuring basic parameters of the air-temperature, relative humidity, carbon dioxide and the value of barometric pressure.

Measurements were carried out with the Testo 435-4 meter with the following accuracy range: temperature $\left(0-50^{\circ} \mathrm{C} \pm 0.3^{\circ} \mathrm{C}\right)$, relative humidity $(2-98 \% \mathrm{RH} \pm 2 \% \mathrm{RH})$, carbon dioxide concentration $(0-10,000 \mathrm{ppm} \pm 100 \mathrm{ppm})$.

The air quality test was carried out on 11.02.2018 between 8:25 am- and 12:10 pm. At that time, two Sunday services were held in the church, in which 128 and 155 people participated. From 8:15 to 8:55 a Benson oil furnace was turned on, injecting heated air into the temple hall. 
Two measuring stations were selected to perform the air quality test. Test stand no. 1 (S-1) was located at the beginning of the nave of the church, at the side altar. The place of measurement was chosen due to the large number of users of the object in a given space. The probe was located about $0.9-1.0 \mathrm{~m}$ above the floor surface, at the level of the head of a sitting man. Test stand no. 2 (S-2) was placed at a height of about $6 \mathrm{~m}$ from the church floor, $0.7 \mathrm{~m}$ above the entresol floor.

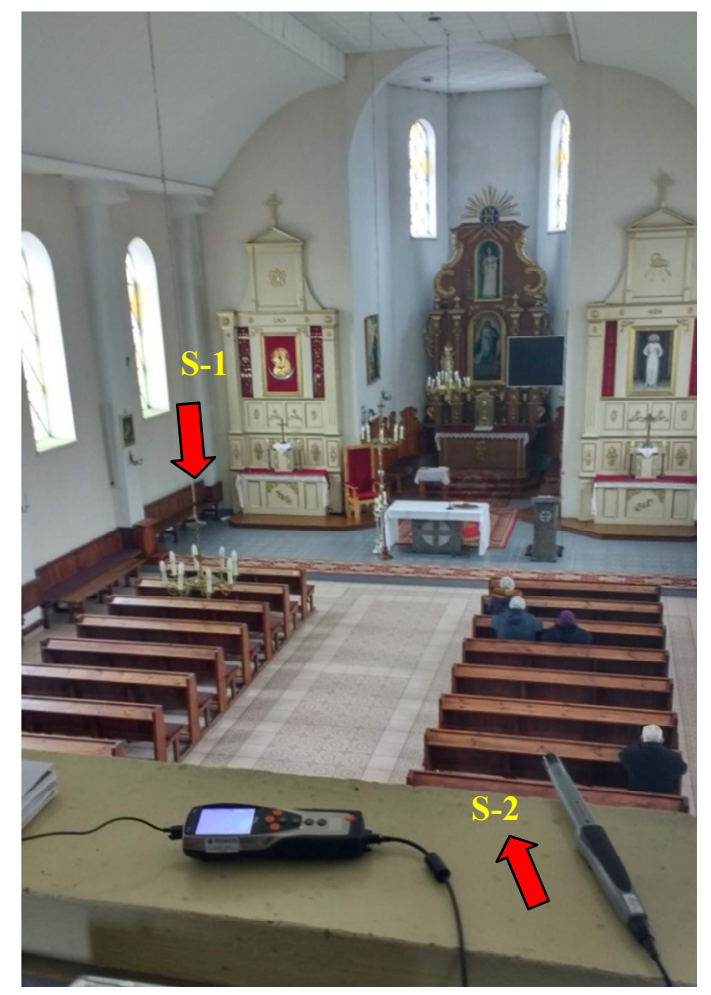

Fig. 3. Location of measuring stands (own collection).

During the Sunday services and the intervals between them, the content of carbon dioxide, relative humidity and temperature were measured. Testo $435-4$ device is programmed in such a way that the measurement is recorded every 1 minute. This is the arithmetic mean of 30 samples.

\section{Results and analysis of measurements}

Tests of basic air quality parameters, i.e. carbon dioxide concentration, temperature and relative humidity level were carried out in the parish church in Tryczówka, at two measuring points: altar (S-1) and entresol (S-2).

The results are shown graphically (Fig. 4, Fig. 5, Fig. 6).

The graph (Fig. 4) shows the results of measurements of carbon dioxide concentration. During the first 10 minutes of the study, the device recorded stabilized minimum measurements: $374 \mathrm{ppm}$ (S-1) and $413 \mathrm{ppm}$ (S-2). At that time there were four people in the temple. At the beginning of the first service at 9.00 (after 35 minutes of research) there were 128 people in the church. The level of $\mathrm{CO}_{2}$ began to increase significantly, at the end of the service, it exceeded the minimum hygiene threshold of 1,000 ppm [12]. During an hour's 


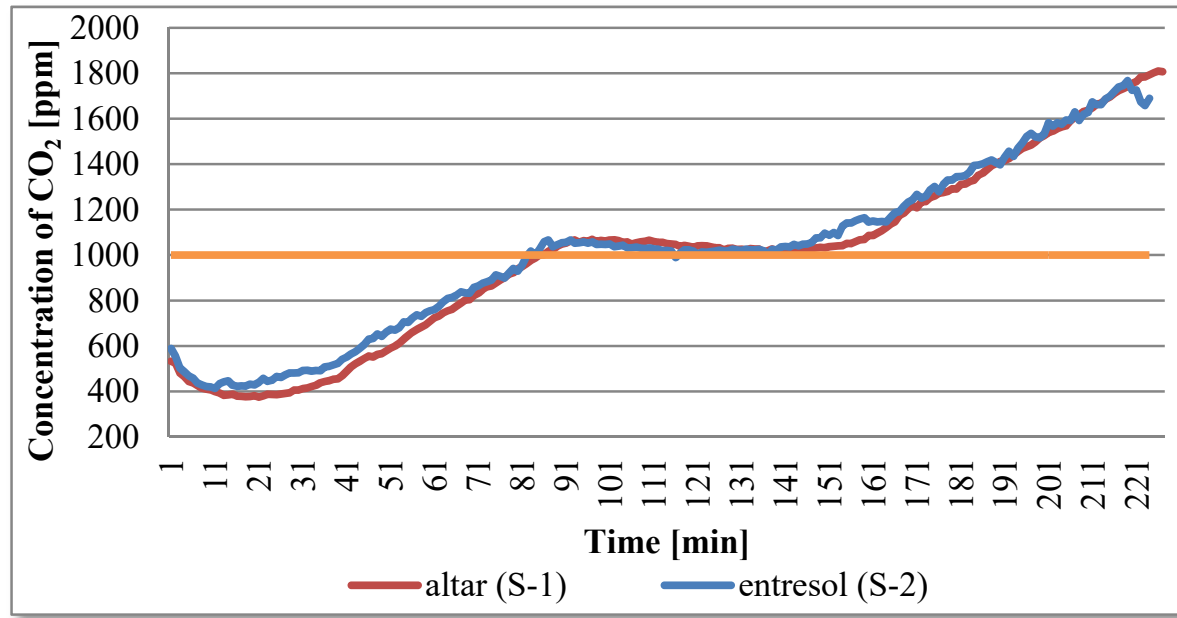

Fig. 4. Concentration of carbon dioxide in a church (date: 11.02.2018, 8.25 a.m.-12.10 p.m.) (own study).

break between meetings, the level of carbon dioxide still fluctuated around 1,000 ppm. Conclusion about low efficiency of the gravity ventilation system and ventilation through the entrance door can be made, because the $\mathrm{CO}_{2}$ concentration remained at the same high level. At the start of the second Sunday service there were 155 people in the church, the $\mathrm{CO}_{2}$ level began to increase again, up to $1,810 \mathrm{ppm}(\mathrm{S}-1)$ and $1,768 \mathrm{ppm}(\mathrm{S}-2)$. In the temple you could feel the stuffiness, breathlessness and stale air.

The next examined parameter was the air temperature (Fig. 5.). High temperature values at the beginning of the test (up to 10 minutes) result from the stabilization of the meter. Between 35 and 95 minutes of research, i.e. during the first mass, the temperature fluctuated within $4^{\circ} \mathrm{C}$, despite the oil furnace, which pressed the heated air into the interior of the church. During the break between the services, the temperature dropped by $1^{\circ} \mathrm{C}$, then, together with the increasing number of building users, it started to increase again to $6.6^{\circ} \mathrm{C}$. Recorded temperatures are definitely below the requirements for thermal comfort and guidelines for equipment $[8,14]$. Very low temperature resulted in feeling of penetrating cold.

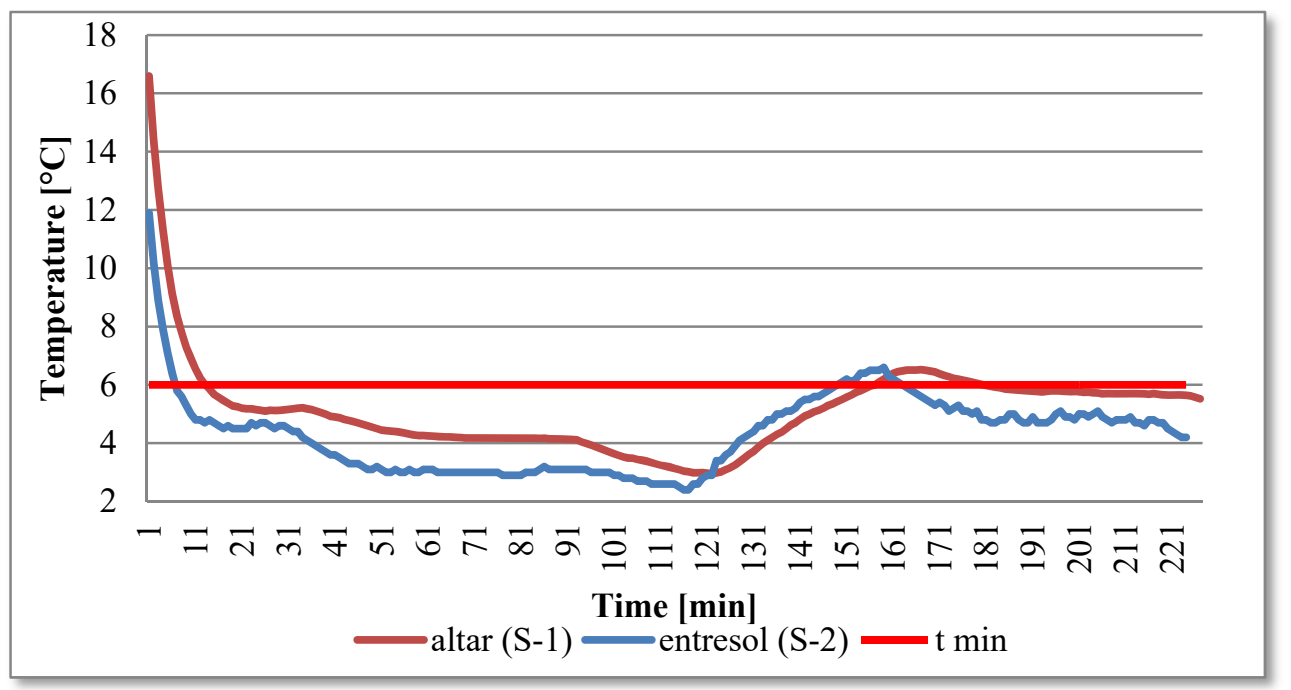

Fig. 5. Temperature in a church (date: $11.02 .2018,8.25$ a.m.-12.10 p.m.) (own study). 


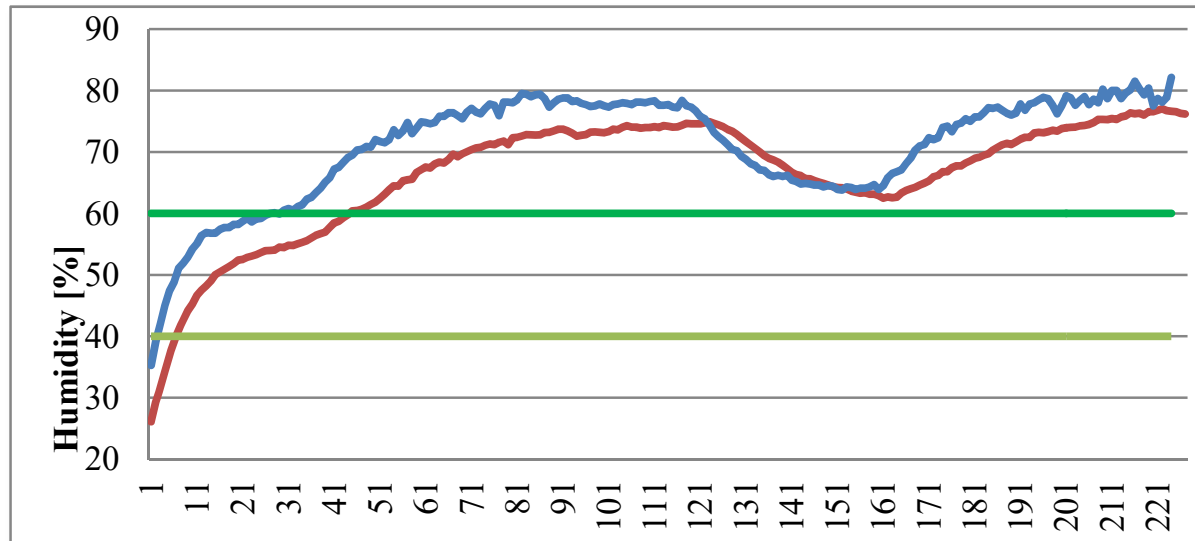

Time [min]

$\longrightarrow \operatorname{altar}(\mathrm{S}-1) \longrightarrow$ entresol (S-2) $=$ RH min $=$ RH max

Fig. 6. Relative humidity in a church (date: $11.02 .2018,8.25$ a.m.-12.10 p.m.) (own study).

Last parameter tested was relative humidity of the air (Fig. 6.). Higher relative humidity was recorded on the S-2 measuring point, located at a height of about $6 \mathrm{~m}$, where the maximum result is $82 \%$. During the time people stayed in the church, as well as during the break, the relative humidity level remained at $60-80 \%$, which, with the recorded temperature of $2.4-6.6^{\circ} \mathrm{C}$, enhanced the feeling of coolness and humidity in the air. Such a high level of relative humidity, combined with low temperature, does not have a positive effect on thermal comfort of building users, and additionally has a destructive effect on the construction and equipment of the building [14, 24].

\section{Summary and conclusions}

The aim of this article is to analyze the results of research on basic parameters of air quality: carbon dioxide, relative humidity and air temperature in the church facility located in the IV climate zone, in the Podlasie Voivodship, in the village of Tryczówka.

The results of the research showed that the concentration of carbon dioxide was too high in relation to the standards, whereas a high level of relative humidity is probably the reason for the development of fungi on the walls of the building.

The analysis carried out on the basis of the research results allowed to state that the measured parameters of air quality - the concentration of carbon dioxide and the level of relative humidity significantly exceeded the recommendations contained in the standards. High concentrations of carbon dioxide, reaching the level of 1,800 ppm, thus significantly exceeding the minimum of hygiene, may cause discomfort to people in the church building. Relative humidity reached a maximum of $82 \%$. Such a high moisture content in the air negatively affects the thermal comfort of users, and additionally has a destructive effect on the structure of the building and its equipment, because it promotes the growth of mold and fungi (Fig. 7, Fig. 8).

In the analyzed facility, there is a need to improve the air quality in terms of carbon dioxide and relative humidity. Ways of improving air quality, such as the installation of mechanical fans, will remove excess moisture and prevent damage to the structure and equipment and improve the comfort of the faithful staying in the church. In addition, there is a need for a thorough analysis of the origin of excess moisture in the air. It is possible that the high relative humidity is caused by moisture coming from the ground, which is why 
we should pay attention to the waterproofing of the building. In addition, the roof of the church must be renovated to stop water infiltration from the upper part of the building. A valid solution is also the use of air dryers that would help remove excess moisture from the air.

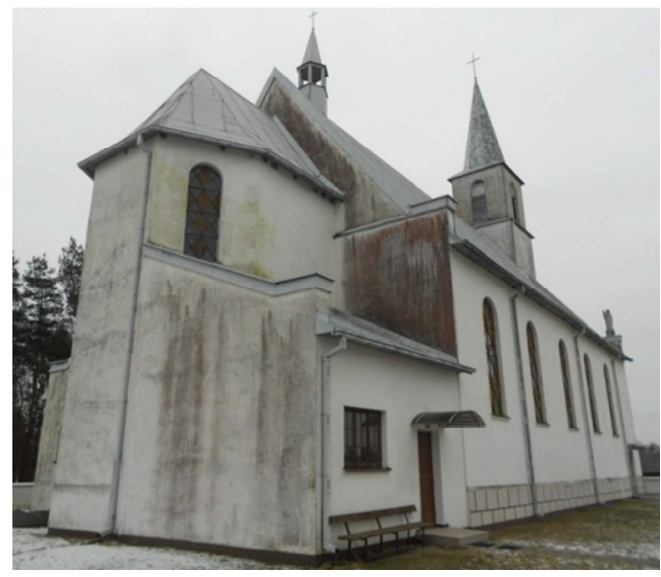

Fig. 7. Fungus on the outside wall. Source: own collection.

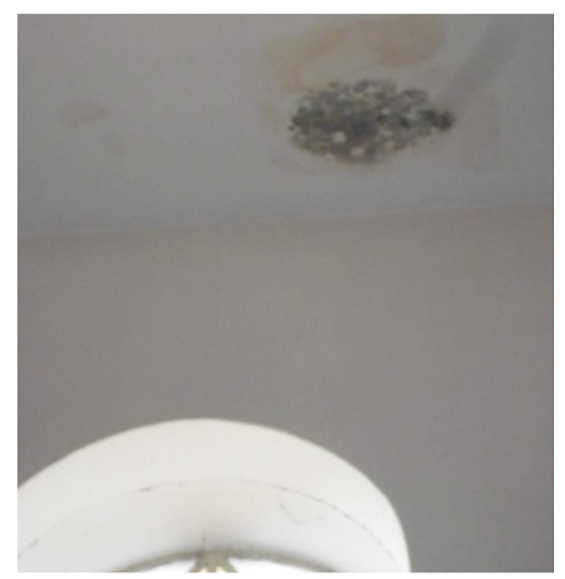

Fig. 8. Fungus inside the building.

\section{References}

1. B. Zabiegała, M. Partyka, J. Namieśnik, Jakość powietrza wewnętrznego -analityka i monitoring, 25 (2003)

2. A. Cincinelli, T. Martellini, Int. Jour. of Env. Res. And Pub. Heal. 14, 11, 1286 (2017)

3. T. Teleszewski, K. Gładyszewska - Fiedoruk, Pol. J. Environ. Stud. 27(5), 1-7 (2018)

4. P. Wargocki, Dwumies. Cyrkul. 1 (2013)

5. D. Camuffo, Microclimate for Cultural Heritage: Conservation, Restoration, and Maintenance of Indoor and Outdoor Monuments (Elsevier Science, 2013)

6. D.A. Krawczyk, K. Gładyszewska - Fiedoruk, A. Rodero, Appl. Therm. Engin. 113, 1088-1096 (2017)

7. M. Śliwowski, Mikroklimat wnętrz i komfort cieplny ludzi w pomieszczeniach (Oficyna Wydawnicza Politechniki Wrocławskiej, Wrocław 1999)

8. E. Vuerich, F. Malaspina, M. Barazutti, T. Georgiadis, M. Nardino. Microchem. Jour. 88(2), 218-23 (2008)

9. M. Wolski, A. Kamiński, Ciepłow. Ogrzew. Wentyl., 7-8 (2006)

10. C. Guerranti, F. Benetti, R. Cucciniello, D. Damiani, G. Perra, A. Proto, F. Rossi, N. Marchettini, Atmosph. Pollut. Res. 7(5), 754-61 (2016)

11. A. Lis, L. Śliwowski, Ciepłow. Ogrzew. Wentyl, 7-8 (2002)

12. M. Taleghani, M. Tenpierik, S. Kurvers, A. Van Den Dobbelsteen, Renew. and Sustain. Ener. Rev. 26, 201-15 (2013)

13. A. Chojnacka, I. Sudoł-Szopińska, Bezpieczeństwo Pracy, 5 (2007)

14. F. E. Turcanu, M. Verdes, I. Serbanoiu, Proc. Technol. 22, 821-828 (2016)

15. M. Napp, T. Kalamees, Ener. \& Build. 108, 61-71 (2015)

16. J. Nazarova, A. Borodiņecs, Constr. Scien. 15(1), 19-23 (2014) 
17. R. Cichowicz, A. Urbaniak, Przegl. Techn. 26 (2008)

18. Y. Tabunschikov, M. Brodatch, Indoor Air 14, 168-174 (2004)

19. W. Wolski, A. Kamiński, A. Krajewska,. Ciepłow. Ogrzew. Wentyl., 6 (2008)

20. M.B. Nantka, Instalacje grzewcze $i$ wentylacyjne $w$ budownictwie, Część 1, „Budynki i ich potrzeby grzewcze $i$ wentylacyjne (Wyd. Politechniki Śląskiej, Gliwice, 2000)

21. PN - EN 13779, Ventilation of residential buildings. Requirements for the properties of ventilation and air conditioning (2008)

22. K. Kaiser, Rynek Instalacyjny, 9 (2010).

23. K. Gładyszewska-Fiedoruk, Transp. Res. Part D, 16(2), 166-171 (2011)

24. M. Danielak, Chłodnictwo i Klimatyzacja, 7 (2017)

25. PN-EN 15757, Conservation of cultural property. Specifications for temperature and relative humidity to limit climate - induced mechanical damage in organic hygroscopic materials (2012)

26. Archival materials of the parish Immaculate Conception of the Blessed Virgin Mary in Tryczówka 